\title{
ASSOCIATION BETWEEN THE DEGREE OF GINGIVAL INFLAMMATION AND 25-HYDROXY VITAMIN D STATUS IN POSTMENOPAUSAL WOMEN
}

\author{
ROBERT FERNANDO ${ }^{1}$, SRI LELYATI C MASULILI ${ }^{1}$, ROBERT LESSANG ${ }^{1 *}$, LINDAWATI S KUSDHANY ${ }^{2}$
}

${ }^{1}$ Department of Periodontics, Faculty of Dentistry, Universitas Indonesia, Jakarta, Indonesia. ${ }^{2}$ Department of Prosthodontics, Faculty of Dentistry, Universitas Indonesia, Jakarta, Indonesia. Email: robertlessang@gmail.com

Received: 16 September 2017, Received and Accepted: 16 October 2017

\section{ABSTRACT}

Objective: To evaluate the association of the degree of gingival inflammation and 25-hydroxy Vitamin D (25(OH)D) level in postmenopausal women.

Methods: A cross-sectional study involved 71 postmenopausal women. Data were obtained using questionnaires, clinical periodontal examinations, and evaluations of blood samples. Serum 25(OH)D concentrations were determined using human 25-dihydroxy Vitamin D ELISA kit.

Result: Prevalence of Vitamin D deficiency among postmenopausal women was 74.64\%. The papillary bleeding index (PBI) was lower (1.07 \pm 0.18$)$ in postmenopausal women with normal serum 25(OH)D levels than that in postmenopausal women with Vitamin D deficiency (1.41 \pm 0.1$)$. However, this difference was not statistically significant $(\mathrm{p}<0.05)$. This result indicated increasing trends in PBI.

Conclusion: There is no association between the degree of gingival inflammation and the 25(OH)D status among postmenopausal women.

Keywords: 25-hydroxy Vitamin D, Papillary bleeding index, Postmenopause.

(c) 2017 The Authors. Published by Innovare Academic Sciences Pvt Ltd. This is an open access article under the CC BY license (http://creativecommons. org/licenses/by/4. 0/) DOI: http://dx.doi.org/10.22159/ijap.2017.v9s2.23

\section{INTRODUCTION}

Menopause is defined as the cessation of menstruation for at least 1 year due to estrogen deficiency. A considerable proportion of the population is affected by estrogen deficiency; there are approximately 70 million women in the United States $>50$ years of age [1]. It is estimated that there will be 60 million menopausal women in Indonesia by 2025 . Currently, in Indonesia, there are 14 million menopausal women, comprising $7.4 \%$ of the total population [2]. Multiple health issues affect postmenopausal women and compromise their quality of life. Postmenopausal women may experience several symptoms [3], including cardiovascular disease, osteoporosis, cancer, cognitive decline and dementia, chronic obstructive pulmonary disease, diabetes mellitus, metabolic syndrome, depression, vasomotor symptoms, sleep disturbances, and migraine $[3,4]$.

Vitamin D and calcium are the basic requirements for bone mineralization and osteoporosis prevention [5]. Vitamin D plays an important role in calcium homeostasis, promoting calcium absorption in the intestines, and stimulating the osteoblasts to enable normal bone growth and preservation [6,7]. Low Vitamin D and calcium intake lead to a negative calcium balance and bone loss; these effects are also believed to occur in the alveolar bone in addition to that in the other bones of the body [7]. Vitamin D formed in the skin and that obtained from the diet is absorbed and accumulates in the liver where it undergoes hydroxylation and metabolization to form 25-hydroxy Vitamin D (25(OH)D), also called calcidiol, the levels of which are used to determine an individual's Vitamin D status [8]

Periodontal disease results in the destruction of the supporting structures of the teeth by an inflammatory process caused by bacterial accumulation on the hard surfaces of the teeth [9].

Vitamin D plays a significant role in bone maintenance and immunity; therefore, it can be inferred that Vitamin D influences the development of periodontal disease [9]. Vitamin D also has anti-inflammatory and antimicrobial properties that may protect against alveolar bone loss and subsequent tooth loss [10]. Vitamin D deficiency may result in an inadequate and prolonged immune reaction to periodontal pathogens, potentially leading to more severe periodontal destruction [9]. To the best of our knowledge, few researches have been conducted on the association between the degree of gingival inflammation and Vitamin D status in postmenopausal women.

The purpose of this study was to evaluate the association between the degree of gingival inflammation and 25(OH)D status in postmenopausal women.

\section{METHODS}

\section{Study population}

Approval for the study on human subjects was obtained from the Ethics Committee of the Faculty of Dentistry, Universitas Indonesia, before study initiation. The sample size calculations were performed using the sample formula for cross-sectional study design, according to which at least 59 subjects needed to be enrolled. The research procedures were explained to all patients after they had read and signed an informed consent document before any treatment.

The investigator screened the patients according to the inclusion and exclusion criteria and selected those who fulfilled the study criteria. Women, aged 50-70 years, who had entered the menopause period (calculated after 1 year of the last menstrual cycle), had no systemic diseases that could influence the outcomes of the therapy, and were willing and able to provide an informed consent were enrolled in the study. Subjects on antibiotic therapy for more than 10 days within the past 3 months of enrollment or those requiring antibiotic prophylaxis, subjects on medications affecting bone metabolism or gingiva, or those with a history of hysterectomy were excluded. Information regarding the subjects' medical histories and medications were collected using a questionnaire [11]. The questionnaire included questions about the physical activity, calcium intake, and sun exposure [11]. Total 71 patients, all of whom were citizens recruited from the Kenari District Office, Central Jakarta, were enrolled in the study. 
Clinical periodontal examination

The periodontal status was assessed by measuring the papillary bleeding index (PBI) (Muhlemann, 1977) [12]. Clinical measurements were recorded by the calibrated investigator using a periodontal probe with $1 \mathrm{~mm}$ markings (Osung, Korea). Calibration was conducted by performing double measurements of a randomly selected patient not involved in the study. Third molars were not included in the clinical assessment because of the substantial variation in their anatomy and position in the oral cavity.

\section{Laboratory analysis}

A venous blood sample was drawn from each subject on the day of the examination. Serum samples were separated after centrifugation at $3000 \mathrm{rpm}$ for $10 \mathrm{~min}$; thereafter, they were stored at $-4^{\circ} \mathrm{C}$ until further assays. These samples were removed from the freezer and defrosted at room temperature before the assays.

All assays were performed in the Integrated Laboratory Faculty of Medicine Universitas Indonesia. Serum 25(OH)D was analyzed using a commercially available enzyme-linked immunoassay (human 25(OH) D ELISA Kit, Qayeebio, Shanghai) according to the manufacturer's instructions. The results are expressed as nanogram per milliliter (range: 7.8-500 ng/mL). For this study, Vitamin D levels were categorized as deficient if the levels were $<30 \mathrm{ng} / \mathrm{mL}$ and adequate if the levels were $\geq 30 \mathrm{ng} / \mathrm{mL}$, as per the guidelines of the Institute of Medicine [13-15].

\section{Statistical analyses}

All statistical analyses were performed using SPSS. Univariate analyses were performed to obtain the mean and standard deviation values of all parameters. Descriptive statistics were obtained, and data were tested for normality using the Kolmogorov-Smirnov test for distribution. Variables that conformed to a normal distribution were analyzed using independent T-tests, while those that showed considerable deviation from the normal distribution were analyzed using the Mann-Whitney $\mathrm{U}$ test and Kruskal-Wallis test to evaluate the statistical significance of the differences between the two groups. $\mathrm{p}<0.05$ was considered statistically significant.

\section{RESULTS}

The distribution of the baseline characteristics of the study population is shown in Table 1.

The tests for normality of the clinical parameters of the postmenopausal women were performed using Shapiro-Wilk test. These tests showed that the distribution of the serum $25(\mathrm{OH}) \mathrm{D}$ levels across age, use of veil, and menopause duration was abnormal $(\mathrm{p}=0.02, \mathrm{p}=0.00$, and $\mathrm{p}=0.00$, respectively)

Table 2 summarizes that there were no significant differences in the serum 25(OH)D levels across age $(p=0.61)$; use of veil $(p=0.71)$; and menopause duration $(\mathrm{p}=0.17)$ among postmenopausal women.

The Shapiro-Wilk test was used to test the normality of the clinical parameters of the postmenopausal women. The result showed that the distribution of serum 25(OH)D levels as per sun exposure was abnormal $(p=0.01)$. The normality test showed that the distribution of PBI was normal $(\mathrm{p}=0.33)$.

This table summarizes that there were no significant differences in the $25(\mathrm{OH}) \mathrm{D}$ status of the postmenopausal women, depending on their sun exposure $(\mathrm{p}=0.68)$ and PBI $(\mathrm{p}=0.12)$ (Table 3$)$.

\section{DISCUSSION}

The supporting tissue of the periodontium is vulnerable to the physiological variations in the levels of circulating hormones in women. Menopause triggers numerous changes in women's bodies, and the oral cavity is also affected [16]. Postmenopausal women are at risk of
Table 1: Demographic, clinical, and laboratory characteristics of postmenopausal women

\begin{tabular}{lll}
\hline Postmenopausal women & n (\%) & Mean (SD) \\
\hline Age (year) & $18(25.35)$ & \\
$\quad 50-54$ & $16(22.53)$ & \\
$55-59$ & $15(21.12)$ & \\
$60-64$ & $22(27.16)$ & \\
$\quad \geq 65$ & & $18(25.35)$ \\
Serum $25(\mathrm{OH}) \mathrm{D}(\mathrm{ng} / \mathrm{ml})$ & & \\
Normal $(\geq 30 \mathrm{ng} / \mathrm{ml})$ & & \\
Deficiency $(<30 \mathrm{ng} / \mathrm{ml})$ & & \\
Use of veil & $43(60.6)$ & \\
$\quad$ Yes & $28(39.4)$ & \\
$\quad$ No & $51(71.8)$ & \\
Menopause duration (years) & $20(28.2)$ & $15.52(2.42)$ \\
$\quad \leq 5$ & & $1.33(0.09)$ \\
$\quad>5$ & & \\
Sun exposure (min/week)* & & \\
PBI* & & \\
\hline
\end{tabular}

*Data are presented as mean and standard deviation. SD: Standard deviation, PBI: Papillary bleeding index

Table 2: Comparative analysis of the serum 25(OH) D levels across age, use of veil, and menopause duration among postmenopausal women

\begin{tabular}{lll}
\hline Postmenopausal women & \multicolumn{1}{c}{ Serum 25 (OH) D Level } & \multirow{2}{*}{$0.61^{*}$} \\
\cline { 2 - 2 } & Mean (SD) (ng/mL) & \\
\cline { 1 - 2 } Age (y) & $27.89(2.1)$ & \\
$50-54$ & $29.26(3.09)$ & \\
$55-59$ & $35.32(5.03)$ & $0.71^{* *}$ \\
$60-64$ & $28.66(2.38)$ & \\
$>65$ & & $0.17^{* *}$ \\
Use of veil & $28.6(2.06)$ & \\
$\quad$ Yes & $30.9(2.21)$ & \\
$\quad$ No & & \\
Menopause & & \\
duration (years) & & \\
$\quad 55$ & $28.7(3.01)$ & \\
$>5$ & $30.52(1.84)$ & \\
\hline
\end{tabular}

*Kruskal-Wallis test, ${ }^{* *}$ Mann-Whitney test; $\mathrm{p}<0.05$ significant. SD: Standard deviation

Table 3: Comparative analysis of the association of sun exposure and the papillary bleeding index with serum $25(\mathrm{OH}) \mathrm{D}$ status among postmenopausal women

\begin{tabular}{|c|c|c|c|}
\hline \multirow{4}{*}{$\begin{array}{l}\text { Postmenopausal } \\
\text { women }\end{array}$} & \multicolumn{2}{|c|}{ Serum $25(\mathrm{OH})$ D status } & \multirow[t]{4}{*}{$\mathbf{p}$} \\
\hline & \multicolumn{2}{|l|}{ Mean (SD) } & \\
\hline & $\begin{array}{l}\text { Normal } \\
(\geq 30 \mathrm{ng} / \mathrm{mL})\end{array}$ & $\begin{array}{l}\text { Deficiency } \\
(<30 \mathrm{ng} / \mathrm{mL})\end{array}$ & \\
\hline & $(n=18)$ & $(n=53)$ & \\
\hline $\begin{array}{l}\text { Sun exposure } \\
\text { (min/week) }\end{array}$ & $16.06(3.95)$ & $15.33(2.97)$ & $0.68^{*}$ \\
\hline PBI & $1.07(0.18)$ & $1.41(0.10)$ & $0.12^{* *}$ \\
\hline
\end{tabular}

*Mann-Whitney test, ${ }^{*}$ independent sample t-test, $\mathrm{p}<0.05$ significant.

SD: Standard deviation, PBI: Papillary bleeding index

Vitamin D deficiency. The findings of this study showed that $74.64 \%$ of postmenopausal women had Vitamin D deficiency (Table 1). Ragab et al. also reported similar results; $68.6 \%$ of the healthy postmenopausal women in their study had Vitamin D deficiency [17]. Yared et al.'s study on postmenopausal Lebanese women with osteoporosis showed a prevalence of $84.9 \%$ for Vitamin D deficiency [18] 
The high prevalence of Vitamin D deficiency among the women in our study may be because many women cover most of their bodies, considering that most of them were Muslim and that most of them wear a veil. In the present study, $60.6 \%$ of the postmenopausal women reported wearing a veil (Table 1), and those who wear veils had lower serum 25(OH)D levels $(28.6 \pm 2.06 \mathrm{ng} / \mathrm{dL})$ than those who do not wear veils $(30.9 \pm 2.21 \mathrm{ng} / \mathrm{dL})$. However, this difference was not statistically significant (Table 2).

This study showed that the women with normal 25(OH)D levels $(16.06$ $\pm 3.95 \mathrm{~min} /$ week) tended to have longer sun exposure than those with Vitamin D deficiency $(15.33 \pm 2.97 \mathrm{~min} /$ week); however, this difference was not statistically significant (Table 3). The major source of Vitamin D is exposure to natural sunlight. Vitamin D produced in the skin lasts at least twice as long in the blood as the ingested Vitamin D [19]. However, topical sunscreen application, increased skin pigmentation, and obesity can substantially reduce Vitamin D synthesis [19]

This study evaluated the association between the degree of gingival inflammation and the 25(OH)D levels in postmenopausal women. The findings from this study demonstrated that the PBI waslower in the women with normal or adequate serum $25(\mathrm{OH})$ D levels $(1.07 \pm 0.18 \mathrm{ng} / \mathrm{mL})$ than in those with Vitamin D deficiency $(1.41 \pm 0.1 \mathrm{ng} / \mathrm{mL})$. However, this difference was not statistically significant (Table 3). Vitamin D deficiency plays a role in dental and oral bone pathologies (altered formation, periodontal disease, and jaw osteonecrosis) [13].

Another study has reported that optimal serum Vitamin D levels may reduce an individual's susceptibility to gingival inflammation and that gingivitis may be a useful clinical indicator to evaluate the antiinflammatory effects of Vitamin D [20]. This finding was supported by the results of a more recent randomized clinical trial that showed a dosedependent anti-inflammatory effect of Vitamin D on gingivitis [21].

Further, Vitamin D may also reduce periodontal disease through its general anti-inflammatory and immunomodulatory effects [22]. For example, the Vitamin D receptor is expressed on several human immune cells, decreases the proliferation of the $\mathrm{T}$ and $\mathrm{B}$ lymphocytes, and inhibits the T-helper (Th1) and Th17 (proinflammatory) cell response, while promoting a Th2 (anti-inflammatory) cell response [23]. Vitamin D may help suppress local inflammation at the site of an oral infection.

This study has some potential limitations that need to be considered. First, the lack of an association between the Vitamin D statue sizes. Second, the validity of the results is also dependent on the correct answers being given by the respondents in the questionnaire rather than only on the clinical evaluations and the medical history. The use of questionnaires has been validated in several studies [11].

\section{CONCLUSION}

There was no association between gingival inflammation and 25(OH)D status among the postmenopausal women in this research.

\section{ACKNOWLEDGMENTS}

The author wishes to acknowledge the assistance of the Kenari District Office, Central Jakarta, regarding the enrolment of the study subjects. This research was financially supported by Hibah PITTA 2017, Universitas Indonesia, Jakarta, Indonesia.

The publication of this manuscript is supported by Universitas Indonesia.

\section{REFERENCES}

1. Goodman NF, Cobin RH, Ginzburg SB, Katz IA, Woode DE, American Association of Clinical Endocrinologists. American association of clinical endocrinologists medical guidelines for clinical practice for the diagnosis and treatment of menopause. Endocr Pract 2011;17 Suppl 6:1-25.

2. Kemenkes RI. Profil Kesehatan Indonesia 2014. Vol. 51. Jakarta: Kementerian Kesehatan RI; 2015. p. 1-6.

3. Fernandez ML, Murillo AG. Postmenopausal women have higher HDL and Decreased incidence of low HDL than premenopausal women with metabolic syndrome. Healthcare (Basel) 2016;4:E20.

4. van Dijk GM, Kavousi M, Troup J, Franco OH. Health issues for menopausal women: The top 11 conditions have common solutions. Maturitas 2015;80:24-30

5. Kemenkes RI. Data dan Kondisi Penyakit Osteoporosisdi Indonesia. Jakarta: Kementerian Kesehatan RI; 2015. p. 1-6.

6. Stein SH, Livada R, Tipton DA. Re-evaluating the role of vitamin D in the periodontium. J Periodontal Res 2014;49:545-53.

7. Lerner UH. Bone remodeling in post-menopausal osteoporosis. J Dent Res 2006;85(7):584-95.

8. Subashree R, Arjunkumar R. Vitamin D deficiency in periodontal health. Res J Pharm Technol 2014;7:248-52.

9. Laky M, Bertl K, Haririan H, Andrukhov O, Seemann R, Volf I, et al. Serum levels of 25-hydroxyvitamin D are associated with periodontal disease. Clin Oral Investig 2016;21:1-6.

10. Pavlesen S. Current vitamin D status and history of tooth loss in postmenopausal women. Thesis. New York: State University of New York; 2014. p. 13-9.

11. Kusdhany LS. Penentuan Indeks Densitas Tulang Mandibula Perempuan Pascamenopause Dengan Memperhatikan Beberapa Faktor Risiko Terjadinya Osteoporosis. Disertation. Jakarta: Universitas Indonesia; 2003. p. 174-80

12. Tatullo M, Gentile S, Paduano F, Santacroce L, Marrelli M. Crosstalk between oral and general health status in e-smokers. Medicine (Baltimore) 2016;95:1-7.

13. Abreu OJ, Tatakis DN, Elias-Boneta AR, López Del Valle L, Hernandez R, Pousa MS, et al. Low vitamin D status strongly associated with periodontitis in Puerto Rican adults. BMC Oral Health 2016;16:89

14. Vieth R. Why the minimum desirable serum 25-hydroxyvitamin $\mathrm{D}$ level should be $75 \mathrm{nmol} / \mathrm{L}$ (30 ng / ml). Best Pract Res Clin Endocrinol Metab 2016;25:681-91

15. Ag E. 25-OH Vitamin D ELISA. Med Labordiagnostika AG 2015; $1: 1-14$

16. Bhardwaj A, Bhardwaj S. Effect of menopause on women's periodontium. J Midlife Health 2012;3:5.

17. Ragab WS, Saleh WF, Tawfik LT. Vitamin D deficiency in postmenopausal Egyptian women. Int J Gynaecol Obstet 2013;123:75-6.

18. Gannagé-Yared MH, Maalouf G, Khalife S, Challita S, Yaghi Y, Ziade N, et al. Prevalence and predictors of vitamin D inadequacy amongst Lebanese osteoporotic women. Br J Nutr 2009;101:487-91.

19. Brock GR, Chapple IL. The potential impact of essential nutrients vitamins $\mathrm{C}$ and $\mathrm{D}$ upon periodontal disease pathogenesis and therapeutic outcomes. Curr Oral Health Rep 2016;3:337-46.

20. Dietrich T, Nunn M, Dawson-Hughes B, Bischoff-Ferrari HA. Association between serum concentrations of 25-hydroxyvitamin D and gingival inflammation. Am J Clin Nutr 2005;82:575-80

21. Hiremath VP, Rao CB, Naik V, Prasad KV. Anti-inflammatory effect of vitamin D on gingivitis: A dose-response randomised control trial. Oral Health Prev Dent 2013;11:61-9.

22. Hewison M. Vitamin D and immune function: An overview. Proc Nutr Soc 2012;71:50-61.

23. Millen AE, Hovey KM, LaMonte MJ, Swansosn M, Andrews CA, Kluczynski MA, et al. Plasma 25-hydroxyvitamin D concentrations and periodontal disease in postmenopause women. J Periodontol 2012;84:1243-56. 